\title{
Article \\ Home-Delivered Meals: Characterization of Food Intake in Elderly Beneficiaries
}

\author{
Ségolène Fleury 1,2,*, Virginie Van Wymelbeke-Delannoy ${ }^{1,3}$, Bruno Lesourd ${ }^{4}$, Paul Tronchon ${ }^{2}$, Isabelle Maître ${ }^{5}$ \\ and Claire Sulmont-Rossé ${ }^{1}$ \\ 1 Centre des Sciences du Goût et de l'Alimentation, AgroSup Dijon, CNRS, INRAE, Université de Bourgogne \\ Franche-Comté, F-21000 Dijon, France; virginie.vanwymelbeke@chu-dijon.fr (V.V.W.-D.); \\ claire.sulmont-rosse@inrae.fr (C.S.-R.) \\ 2 Saveurs et Vie, 94390 Orly, France; paul.tronchon@saveursetvie.fr \\ 3 CHU Dijon Bourgogne, F-21000 Dijon, France \\ 4 Département de Gériatrie CHU, 63000 Clermont-Ferrand, France; lesourd.bruno@orange.fr \\ 5 USC 1422 GRAPPE, Ecole Supérieure d'Agricultures (ESA), SFR 4207 QUASAV, INRAE, 55 rue Rabelais, \\ 49007 Angers, France; i.maitre@groupe-esa.com \\ * Correspondence: segolene.fleury@saveursetvie.fr
}

check for

updates

Citation: Fleury, S.; Van

Wymelbeke-Delannoy, V.; Lesourd, B.;

Tronchon, P.; Maître, I.; Sulmont-Rossé,

C. Home-Delivered Meals:

Characterization of Food Intake in Elderly Beneficiaries. Nutrients 2021, 13, 2064. https://doi.org/10.3390/ nu13062064

Academic Editor: Matthew C. Lohman

Received: 11 May 2021

Accepted: 11 June 2021

Published: 16 June 2021

Publisher's Note: MDPI stays neutral with regard to jurisdictional claims in published maps and institutional affiliations.

Copyright: (c) 2021 by the authors. Licensee MDPI, Basel, Switzerland. This article is an open access article distributed under the terms and conditions of the Creative Commons Attribution (CC BY) license (https:/ / creativecommons.org/licenses/by/ $4.0 /)$.

\begin{abstract}
Objective. In this study, we focus on elderly people ( $\geq 70$ years old) benefiting from a home delivery meal service as part of a social welfare program. We aimed to: (i) assess the gap between the recommended and actual nutritional intake in this population and (ii) study the relationship between the intake of nutrients and the variables characterizing the participants' health and nutritional status. Design. A dietary survey (24-hour record) was conducted during a home interview, with 64 people receiving a home delivery meal service (75\% women; 70-97 years old). At the same time, the participants answered questionnaires assessing their nutritional and health status. Results. Our data showed that the consumption of 70 to $80 \%$ participants was not sufficient for reaching the nutritional recommendations for energy and macronutrients. Additionally, the data showed that the lower the energy and protein intakes, the higher the risk of malnutrition. In addition, one third of the participants were both overweight or obese and at risk of undernutrition or undernourished. Our study demonstrated that the heavier the person, the more difficult it was for them to meet the nutritional recommendations based on kilograms of body weight. Finally, individuals receiving two to three delivered meals per day had higher energy and protein intakes than those receiving a single meal. Conclusion. These results suggest that it is important that home meal delivery companies improve the quality of their meals and service so that their recipients can better meet nutritional recommendations.
\end{abstract}

Keywords: older adults; nutritional intake; home care services; meals-on-wheels; protein-energy malnutrition

\section{Introduction}

With advancing age, the onset of physical and/or cognitive disabilities may lead older adults to seek help in activities of daily living. In the home, this assistance is essentially focused on shopping or meal preparation [1], and it can be provided by a family member (child, spouse) or a professional caregiver (household helper, life assistant). Among the various care offers, meal delivery service (also known as meals-on-wheels) can provide dependent elderly people with a solution for maintaining balanced and regular nutritional intake [2]. Several studies have shown a positive impact of home delivered meals on nutritional intake and/or nutritional status [3-15]. For example, Roy \& Payette, (2006) showed that, among people over 65 years who requested a homecare service, the implementation of meal delivery service resulted in a significant increase in energy and protein intake after eight weeks of follow-up, while no change was observed among 
the people who did not subscribe to this service [11]. However, several studies have also shown that a significant proportion of beneficiaries did not meet their nutritional needs [13,16-22]. For example, in the study conducted by Ponza, (1996), which included 818 beneficiaries of an American home-delivered meal service, $44 \%$ of beneficiaries did not meet one-third of the energy recommendations and $14 \%$ did not meet one-third of the protein recommendations [21].

In Anses report, which was a response to the referral $n^{\circ} 2012-S A-0103$ in order to update the nutritional references [23], a person's energy needs only decrease by 7 to $18 \%$ between 40-49 years and 60-69 years. In the elderly population, the French Health Authorities (HAS, 2007) recommends a daily intake of $30 \mathrm{kcal}$ per $\mathrm{kg}$ of body weight [24]. Regarding protein intake, work that was conducted by the PROT-AGE consortium Bauer et al., [25] and by the European Society for Enteral and Parenteral Nutrition (ESPEN) [26] recommended an intake of 1 to $1.2 \mathrm{~g}$ per day and per $\mathrm{kg}$ of body weight beyond the age of 60 ( $1.5 \mathrm{~g}$ in the case of illness), when compared to 0.8 to $1 \mathrm{~g}$ per $\mathrm{kg}$ of body weight in younger individuals. Several factors may explain this increase in protein requirements with age. On the one hand, advancing age is accompanied by changes in the digestive system that may alter nutrient absorption [27]. On the other hand, there is resistance to the positive effects of dietary protein on protein synthesis, a phenomenon that is known as anabolic resistance. For instance, it has been shown that a denser bolus of amino acids is needed for stimulating muscle protein synthesis in older people as compared to younger individuals [28,29]. Finally, the elderly may also have higher protein requirements to compensate for a higher base metabolism in inflammatory conditions. In the elderly, insufficient food intake is associated with an increased risk of undernutrition [30]. Subsequently, undernutrition is associated with numerous negative consequences in this same population, including muscle loss, impaired immune defenses, poor wound healing, aggravation of existing diseases, and impaired functional and muscular capacities [31,32]. Without care, it can induce or aggravate frailty and/or dependence, which can finally affect the quality of life and life expectancy of the elderly [33,34]. Conversely, Salminen et al. (2020) showed that adequate energy intake can prevent frailty and maintain a good quality of life [35].

In France, meals-on-wheels involves 80,000 people. This activity belongs to the medicosocial sector of collective catering alongside hospital and nursing home catering [36]. This service can be offered by local authorities or associations in the social action framework. In fact, $66 \%$ of the French municipalities accounting for 5000 to 20,000 inhabitants offer a meal delivery service to the most deprived and/or dependent elderly [37]. However, the older population benefitting from a meal delivery service has been seldom studied in France, according to the systematic literature review conducted by Fleury et al. [38]. In the present study, we have characterized the food intake of the elderly people benefiting from a home-delivered meal service provided by the social services of the city of Paris. The objective of our study was to: (i) evaluate energy and macronutrient intakes and the gap between consumption and recommendations; and (ii) study the relationship between food intake, weight status, and nutritional status, as well as observe the influence of physical and health status on the previous factors.

\section{Materials and Methods}

\subsection{Participants}

People that were over 70 years old receiving at least five meals per week from the home meal delivery service of the Social Services of Paris were sent a letter describing the study, and they were then contacted by telephone. Those who agreed to participate in the study were visited by a dietician to obtain their informed consent after presenting the study and providing complete documentation. Individuals suffering from an acute illness at the time of the visit were excluded from the study. The sample size was calculated from the prevalence of people not meeting the dietary recommendations, as recently reported by Borkent et al. [39]. In this study, $71 \%$ of the population had an inadequate intake that met the recommended protein intakes. With a $95 \%$ confidence level and a margin of error 
set at $10 \%$, the study sample size was set as 79 participants. We were secured with a $20 \%$ dropout rate and planned to recruit approximately 100 individuals.

\subsection{Interviews}

A dietitian visited each participant at home for a face-to-face interview lasting approximately 60-90 min. During this session, detailed data were collected through questionnaires and tests. The experimental protocol was approved by the appropriate French ethics committee (CPP ESTI 2015/24-IDRCB N 2015-A01324-45).

\subsection{Socio-Demographic Data}

The socio-demographic variables included age, gender, marital status (couple, single, widowed), education level (none, primary, secondary, higher), and self-perceived financial situation (fragile, average, comfortable).

\subsection{Food Intake Measurement}

Food intake was assessed using a 24-hour record on a meal delivery day (for participants not receiving a meal every day-excluding weekends) [40-42]. Oral nutritional supplements were not prescribed to all participants whose nutritional status required them and, therefore, were not considered in the food intake measurement. The dietitian called the participant in the morning to remind him/her to carefully record their food intake for the day. The dietitian filled out a record book with the participant during the visit the following day. When the participants had difficulty remembering what they had eaten the day before, the dietitian would check the home delivery meals menu and check their refrigerators to see whether there were some leftovers. Macronutrient intakes (energy, protein, carbohydrate, fat), total daily nutrient intakes (TDIs), and daily nutrient intakes relative to body weight (DNIs) were determined from the Ciqual French Food Composition Table (2016) [43].

\subsubsection{Nutritional Status Characterization}

The nutritional variables included Body Mass Index (BMI) measurement and the Mini-Nutritional Assessment (MNA). Body weight was measured using an electronic scale $\left(\right.$ TERRAILLON $^{\circledR}$ ). The participants were weighed with their clothing, and the weight was adjusted by subtracting the average weight of the clothes they wore [44]. Height was recorded from the person's ID card or it was calculated based on the lower leg length using the Chumlea formula [45]. The lower leg length was measured using a height gauge, with the ankle and knee at a $90^{\circ}$ angle. The MNA is an 18-item questionnaire that includes anthropometric measures (weight, arm, and calf circumferences), as well as nutrition and health questions. This questionnaire defines a score between 0 and 30 [46]: a score below 17 indicates undernourished status; a score between 17 and 23.5 indicates a risk of undernutrition; and a score above 23.5 indicates normal nutritional status.

\subsubsection{Physical, Psychological, and Cognitive Status Characterization}

Comorbidities. The participants were asked to report any illnesses during the interview and, when possible, provide a copy of their latest medical prescriptions. A physician (co-author BL) analyzed these data to determine the number of comorbidities for each participant (e.g., cardiovascular disease, neuropsychiatric disease, metabolic disease ... ).

Functional capacities. Participants took two of the Short Physical Performance Battery (SPPB) tests [47]: chair lift, which is the time that is required to stand up from a chair without using the armrests five times in a row, and walking speed over four meters without assistance. Because many participants were unable to complete the tests without the help of armrests (36 participants out of 60) or a cane/walker (21 participants), the scores that were proposed in the SPPB were adapted to allow for a better gradation of the participants' physical capacities (Table 1). The chair lift and walking speed scores were 
added together to obtain a score between 0 (worst functional performance) and 18 (best functional performance).

Table 1. The adaptation of chair lift and walking speed scores (SPPB).

\begin{tabular}{cc}
\hline SPPB Initial Scores & Modified Scores \\
\hline & Chair lift ${ }^{\text {a }}$ \\
\hline 0: test not performed & $0:$ no chair lift \\
$1: 1$ or 2 chair lifts \\
$2: 3$ or 4 chair lifts \\
1: test duration $\geq 16.7$ seconds & 4: test duration $[16.6,13.6]$ seconds with help \\
2: test duration $[16.6,13.7]$ seconds & 5: test duration $[13.6,11.2]$ seconds with help \\
3: test duration $[13.6,11.2]$ seconds & 6: test duration $\leq 11.1$ seconds with help \\
4: test duration $\leq 11.1$ seconds & 7: test duration $\geq 16.7$ seconds without help \\
& 8: test duration $[16.6,13.6]$ seconds without help \\
& 9: test duration $[13.6,11.2]$ seconds without help \\
& 10: test duration $\leq 11.1$ seconds without help \\
\hline
\end{tabular}

Walking speed ${ }^{b}$

\begin{tabular}{cc} 
& Walking speed ${ }^{\mathbf{b}}$ \\
\hline 0: test not performed & 0: test not performed \\
1: test duration $\geq 9.3$ seconds & 1: test duration $\geq 9.3$ seconds with help \\
2: test duration $[6.7 ; 9.2]$ seconds & 3: test duration $[5.7,9.2]$ seconds with help \\
3: test duration $[5.2 ; 6.6]$ seconds & 4: test duration $\leq 5.1$ seconds with help \\
4: test duration $\leq 5.1$ seconds & 5: test duration $\geq 9.3$ seconds without help \\
& 6: test duration $[6.7,9.2]$ seconds without help \\
& 7: test duration $[5.2,6.6]$ seconds without help \\
8: test duration $\leq 5.1$ seconds without help
\end{tabular}

a Chair lift with help: the person used the chair armrests to get up; ${ }^{\mathrm{b}}$ Walking test with help: the person used a cane or walker to walk.

Cognitive status. The participants completed the Mini Mental State Examination (MMSE) questionnaire. The MMSE consists of 11 questions that assess the following cognitive abilities: orientation, learning, attention, memory, language, and praxis. The score ranges from 0 (worst cognitive performance) to 30 (best cognitive performance) [48].

Depression. Participants completed the short version of the Geriatric Depression Scale (GDS) questionnaire. This version includes 15 items [49,50]. The respondents answered "yes" or "no" for each question (e.g., "Are you satisfied with your life?"; "Do you get bored often?"). The GDS score ranges from 0 to 15 (the higher the score, the more depressed the person).

\subsection{Data Analysis}

Descriptive variables were presented as percentages or means $(\mathrm{M})$ associated with standard deviations (SD). Firstly, a univariate mixed linear model was performed with energy and protein intakes as dependent variables, and each of the other variables were measured as independent variables. Secondly, multiple linear regressions were only conducted with the independent variables that are associated with a significant trend or effect $(p<0.10)$. These regressions were performed using the GLM procedure of the SAS software (SAS Institute Inc., Cary, NC, USA).

\section{Results}

\subsection{Participant Characterization}

At the time of the study, there were 1607 older people receiving home meal delivery service of the Social Services of Paris. Approximately half of these people were randomly selected to be contacted. However, after seven months of recruitment and 694 telephone calls, we managed to include only 64 participants (proportion of women: $75 \%$; average 
age: $83 \pm 7$ years; age range: $70-97$ years). One-third of those contacted did not answer the telephone and $84 \%$ of those contacted refused to participate in the study. The main reasons for refusal were fatigue or the constraints associated with seeing a dietician at home.

Table 2 displays the characteristics of the participants included in the study. In terms of the frequency of meal delivery, 44 participants received one meal per day maximum (between four and seven meals per week, mainly lunch) and 20 participants received between two and three meals per day (between 13 and 21 meals per week, including breakfast, lunch, and dinner). A low level of education was reported by $41 \%$ of the participants ('no education' or 'no longer in school after primary school') and 60\% reported being in a fragile financial situation. The participants had rather low functional abilities (average BPSS score of 7.2/18). On average, the participants had three comorbidities and a high BMI, with $55 \%$ of the participants being overweight or obese.

Table 2. Participant characteristics. Means are presented with standard deviations (in parentheses). The values in brackets are the minimum and maximum values.

\begin{tabular}{|c|c|}
\hline Variables & Participants $(n=64)$ \\
\hline$\%$ of women & $75 \%$ \\
\hline Age & 83.4 (7.5) (70-97) \\
\hline \multicolumn{2}{|l|}{ Number of meals delivered per week } \\
\hline$\leq 7$ meals per week & $69 \%$ \\
\hline Between 13 et 21 meals per week & $31 \%$ \\
\hline \multicolumn{2}{|l|}{ Marital status } \\
\hline Alone $^{\mathrm{a}}$ & $51 \%$ \\
\hline Couple & $44 \%$ \\
\hline Widow & $5 \%$ \\
\hline \multicolumn{2}{|l|}{ Education level } \\
\hline No & $14 \%$ \\
\hline Primary & $27 \%$ \\
\hline Secondary & $33 \%$ \\
\hline Graduate & $26 \%$ \\
\hline \multicolumn{2}{|l|}{ Self-perception of financial resources } \\
\hline low & $60 \%$ \\
\hline Fair & $31 \%$ \\
\hline Good & $9 \%$ \\
\hline \multicolumn{2}{|l|}{ Nutritional statut } \\
\hline Body Mass Index (BMI) & $26.1(6.1)(15-46)$ \\
\hline Underweight & $6 \%$ \\
\hline Normal body weight & $39 \%$ \\
\hline Overweight & $33 \%$ \\
\hline Obese & $22 \%$ \\
\hline Mini Nutritional Assessment (MNA) & $20.1(3.8)(10-26)$ \\
\hline Normal & $22 \%$ \\
\hline Risk of malnourishment & $61 \%$ \\
\hline Malnourishment & $17 \%$ \\
\hline \multicolumn{2}{|l|}{ Physical, psychological, and cognitive status } \\
\hline Number of comorbidities & $3.4(1.6)[0-8]$ \\
\hline Short Physical Performance Battery (SPPB) & $7.2(5.2)[0-14]$ \\
\hline Chair lift & $3.0(2.4)[0-8]$ \\
\hline Walking test & $4.2(3.4)[0-8]$ \\
\hline Mini-Mental State Examination (MMSE) & 25.9 (3.9) [14-30] \\
\hline Geriatric Depression Scale (GDS) & $4.9(3.4)[0-14]$ \\
\hline
\end{tabular}

a Single and divorced. The MNA score varies from 0 to 30 (the higher the score, the better the nutritional status). The BPSS score varies from 0 to 18 (the higher the score, the better the functional abilities). The MMSE score varies from 0 to 30 (the higher the score, the better the cognitive performance). The GDS score varies from 0 to 15 (the higher the score, the greater the depression).

\subsection{Nutritional Intakes}

Table 3 presents the total daily nutrient intakes (TDIs) and daily nutrient intakes relative to body weight (DNIs), which were determined for macronutrients (energy, protein, 
carbohydrates, and fat) from food records. These were compared to the recommended dietary allowances (RDAs) for this population (Bresson \& Mariotti, 2016; Deutz et al., 2014). The results show that between $70 \%$ and $80 \%$ of the participants do not eat enough to meet the nutritional recommendations. For these participants, the average deficit between recommended and total intakes is about $872(\mathrm{SD}=524) \mathrm{kcal}, 33(\mathrm{SD}=20) \mathrm{g}$ protein, 105 $(\mathrm{SD}=59) \mathrm{g}$ carbohydrate, and $35(\mathrm{SD}=21) \mathrm{g}$ fat.

Table 3. Daily Nutrient Intakes (TDI and DNI) as compared to Recommended Nutrient Intake (RNI). Means are presented with their standard deviation (in parentheses).

\begin{tabular}{ccccc}
\hline Nutrients & TDI & DNI & $\begin{array}{c}\text { RNI per kg of Body } \\
\text { Weight }\end{array}$ & \% Deficient ${ }^{\mathbf{~}^{\prime}}$ \\
\hline Energy (kcal) & $1306(369)$ & $20.0(7.0)$ & 30.0 & $83 \%$ \\
Proteins (g) & $58(21)$ & $0.9(0.4)$ & 1.2 & $72 \%$ \\
Carbohydrates (g) & $152(48)$ & $2.4(1.1)$ & 3.5 & $81 \%$ \\
Lipids (g) & $48(18)$ & $0.8(0.3)$ & 1.1 & $75 \%$ \\
\hline
\end{tabular}

TDI: Total Daily nutrient intake; DNI: Daily Nutrient Intake relative to body weight; RNI: Recommended Nutrient Intake; ${ }^{1}$ Percentage of participants whose DNI were below the RNI per kg of body weight for the macronutrient of interest.

\subsection{Nutritional Status}

Table 4 presents the prevalence of nutritional risk in the total sample and by weight status categories. According to the Mini Nutritional Assessment, 39 participants (61\%) were at risk of undernutrition and $11(17 \%)$ were undernourished. It is interesting to note that, among the participants at risk of undernutrition or undernourished, 24 participants $(48 \%)$ were overweight or obese. The prevalence of nutritional risk appears to be higher among obese individuals (13 out of $14 ; 93 \%$ ) than among overweight individuals (11 out of $21 ; 52 \%)$. Nevertheless, this result should be confirmed in a larger population. Finally, all of the underweight individuals were at risk of malnutrition or undernourishment.

Table 4. The prevalence of nutritional risk (MNA) by weight status categories (BMI).

\begin{tabular}{|c|c|c|c|c|c|}
\hline \multirow[b]{2}{*}{ Nutritional Status (MNA) } & \multicolumn{4}{|c|}{ Body Mass Index (BMI) } & \multirow[b]{2}{*}{ Total } \\
\hline & $\begin{array}{l}\text { Underweight } \\
\qquad<21\end{array}$ & $\begin{array}{c}\text { Normal } \\
21-24\end{array}$ & $\begin{array}{c}\text { Overweight } \\
25-29\end{array}$ & $\begin{array}{c}\text { Obese } \\
>30\end{array}$ & \\
\hline \multicolumn{6}{|l|}{ Normal $>23.5$} \\
\hline$n$ & 0 & 3 & 10 & 1 & 14 \\
\hline$\%$ & $0 \%$ & $4.5 \%$ & $16 \%$ & $1.5 \%$ & $22 \%$ \\
\hline \multicolumn{6}{|l|}{ At risk of malnutrition $23.5-17$} \\
\hline$n$ & 4 & 13 & 10 & 12 & 39 \\
\hline$\%$ & $6 \%$ & $20 \%$ & $16 \%$ & $19 \%$ & $61 \%$ \\
\hline \multicolumn{6}{|l|}{ Malnutrition $<17$} \\
\hline$n$ & 5 & 4 & 1 & 1 & 11 \\
\hline$\%$ & $8 \%$ & $6 \%$ & $1.5 \%$ & $1.5 \%$ & $17 \%$ \\
\hline \multicolumn{6}{|l|}{ Total } \\
\hline$n$ & 9 & 20 & 21 & 14 & 64 \\
\hline$\%$ & $14 \%$ & $31 \%$ & $33 \%$ & $22 \%$ & $100 \%$ \\
\hline
\end{tabular}

\subsection{Univariate Regression Results}

Table 5 presents the results of the linear univariate regression models for energy and protein TDIs and DNIs. No significant relationship was observed between the energy or protein intakes and socio-demographic variables (gender, age, marital status, education, and financial status). TDIs were significantly and positively associated with nutritional status, as defined by the MNA score and the number of co-morbidities. DNIs were positively associated with the SPPB score (significant for energy, trend for protein). Weight status (BMI) was significantly associated with TDIs and DNIs, except for total daily energy 
intake (positively with TDIs and negatively with DNIs). Finally, energy and protein intakes, both TDIs and DNIs, were all significantly and positively associated with the number of meals delivered per day.

Table 5. The result of analyses in the univariate mixed linear model. The $\beta$ coefficients are associated with their $5 \%$ confidence interval (CI) and the significance threshold: $\left({ }^{*}\right): p<0.10 ;{ }^{*} p<0.05 ;{ }^{* *} p<0.01 ; * * *<0.001$.

\begin{tabular}{|c|c|c|c|c|c|c|c|c|}
\hline & \multicolumn{4}{|c|}{ Energy } & \multicolumn{4}{|c|}{ Protein } \\
\hline & \multicolumn{2}{|r|}{ TDI } & \multicolumn{2}{|c|}{ DNI } & \multicolumn{2}{|r|}{ TDI } & \multicolumn{2}{|c|}{ DNI } \\
\hline & $\beta$ & CI & $\beta$ & CI & $\beta$ & $\mathrm{CI}$ & $\beta$ & CI \\
\hline \multicolumn{9}{|c|}{ Sex (reference: man) } \\
\hline Woman & -77.73 & {$[-299.36 ; 143.90]$} & 1.02 & {$[-3.34 ; 5.39]$} & -9.37 & {$[-22.09 ; 3.35]$} & -0.04 & {$[-0.28 ; 0.19]$} \\
\hline Age & -8.91 & {$[-22.04 ; 4.21]$} & -0.10 & {$[-0.36 ; 0.16]$} & -0.53 & {$[-1.30 ; 0.23]$} & -0.01 & {$[-0.02 ; 0.01]$} \\
\hline \multicolumn{9}{|c|}{ Marital status (reference: single) } \\
\hline Couple & 141.92 & {$[-310.18 ; 594.02]$} & 2.75 & {$[-6.11 ; 11.61]$} & 14.36 & {$[-11.52 ; 40.25]$} & 0.31 & {$[-0.16 ; 0.79]$} \\
\hline Widow & -42.41 & {$[-242.47 ; 157.64]$} & 1.77 & {$[-2.15 ; 5.69]$} & -5.38 & {$[-16.83 ; 6.08]$} & 0.03 & {$[-0.18 ; 0.24]$} \\
\hline \multicolumn{9}{|c|}{ Education level (reference: no) } \\
\hline Primary & -113.28 & {$[-428.94 ; 202.37]$} & -1.59 & {$[-8.03 ; 4.89]$} & -5.74 & {$[-24.30 ; 12.82]$} & -0.08 & {$[-0.41 ; 0.26]$} \\
\hline Secondary & 142.80 & {$[-158.81 ; 444.42]$} & -0.50 & {$[-6.70 ; 5.70]$} & 1.62 & {$[-16.12 ; 19.35]$} & -0.08 & {$[-0.41 ; 0.24]$} \\
\hline Graduate & 154.55 & {$[-157.65 ; 466.76]$} & 0.50 & {$[-5.92 ; 6.91]$} & 10.53 & {$[-7.83 ; 28.89]$} & 0.16 & {$[-0.17 ; 0.50]$} \\
\hline \multicolumn{9}{|c|}{ Self-perception of financial resources (reference: low) } \\
\hline Fair & -52.80 & {$[-263.89 ; 158.29]$} & 2.29 & {$[-1.83 ; 6.42]$} & -2.69 & {$[-15.05 ; 9.67]$} & 0.06 & {$[-0.16 ; 0.29]$} \\
\hline good & -190.44 & {$[-582.78 ; 201.90]$} & -1.68 & {$[-9.35 ; 5.98]$} & -6.43 & {$[-29.40 ; 16.54]$} & 0.22 & {$[-0.19 ; 0.63]$} \\
\hline BMI & 12.09 & {$[-3.34 ; 27.52]$} & $-0.60 * * *$ & {$[-0.87 ;-0.34]$} & $1.11^{* *}$ & {$[0.23 ; 1.97]$} & $-0.02 * *$ & {$[-0.04 ;-0.01]$} \\
\hline \multicolumn{9}{|c|}{ Number of meals delivered per week (reference: $\leq 1$ meal per day) } \\
\hline $\begin{array}{c}>1 \\
\text { meal/day }\end{array}$ & $335.76^{* * *}$ & {$[151.39 ; 520.13]$} & $5.64^{* *}$ & {$[1.91 ;-9.38]$} & $16.50 * *$ & {$[5.41 ; 27.59]$} & $0.31 * *$ & {$[0.11 ; 0.51]$} \\
\hline MNA & $27.42 *$ & {$[2.73 ; 52.11]$} & -0.09 & {$[-0.59 ; 0.42]$} & $1.48^{*}$ & {$[0.04 ; 2.93]$} & -0.01 & {$[-0.04 ; 0.01]$} \\
\hline Comorbidities & $65.64 *$ & {$[7.13 ; 124.15]$} & -0.06 & {$[-1.26 ; 1.14]$} & $5.56^{* * *}$ & {$[2.32 ; 8.79]$} & 0.04 & {$[-0.02 ; 0.10]$} \\
\hline SPPB & -0.84 & {$[-19.55 ; 17.87]$} & $0.43^{* *}$ & {$[0.08 ; 0.78]$} & -0.17 & {$[-1.26 ; 0.92]$} & $0.02\left(^{*}\right)$ & {$[0.00 ; 0.04]$} \\
\hline MMSE & 3.20 & {$[-22.60 ; 29.00]$} & -0.04 & {$[-0.55 ; 0.47]$} & -0.09 & {$[-1.60 ; 1.41]$} & -0.01 & {$[-0.03 ; 0.03]$} \\
\hline GDS & 1.12 & {$[-27.77 ; 30.02]$} & -0.07 & {$[-0.64 ; 0.49]$} & 0.84 & {$[-0.83 ; 2.51]$} & 0.01 & {$[-0.02 ; 0.04]$} \\
\hline
\end{tabular}

TDI: Total Daily nutrient Intake; DNI: Daily Nutrient Intake relative to body weight; BMI: Body Mass Index; MNA: Mini-Nutritional Assessment; SPPB: Short Physical Performance Battery; MMSE: Mini-Mental State Examination; GDS: Geriatric Depression Scale.

\subsection{Multiple Regression Results}

In multiple linear regression models, the total daily energy intake remained significantly associated with the MNA score $(\beta=38.44$; CI: $[17.46 / 59.43] ; p<0.001)$ and the number of comorbidities $(\beta=70.78 ; C I$ : $[20.92 ; 120.63] ; p<0.01)$. Similarly, the total daily protein intake was significantly associated with the MNA score $(\beta=2.10 ; \mathrm{CI}$ : [0.85/3.35]; $p<0.001)$ and the number of comorbidities $(\beta=5.44 ; \mathrm{CI}$ : $[2.16 ; 8.71] ; p<0.01)$. While the total daily energy and protein intakes increased with the number of co-morbidities, we found that the lower the total daily energy and protein intakes, the greater the nutritional risk (the lower the MNA score).

Energy intake was significantly associated with BMI when intakes are divided by the body weight (DNIs) $(\beta=-0.56$; CI: $[-0.83 ;-0.30] ; p<0.001)$. Figure 1 illustrates the relationship between DNIs and BMI: as BMI increased, the daily intake relative to body weight decreased. Thus, the average daily energy intake per kg body weight was $21.2 \mathrm{kcal}$ $(\mathrm{SD}=6.2)$ for people with normal weight status and $15.1 \mathrm{kcal}(\mathrm{SD}=3.8)$ for people with obesity. When considering the recommendation of $30 \mathrm{kcal} / \mathrm{kg}$ body weight per day, a corollary of this result is that people had greater difficulty in meeting the recommendations as BMI increased. A similar result pattern was observed for protein per $\mathrm{kg}$ body weight 
( $\beta=-0.02 ; \mathrm{CI}:[-0.04 ;-0.01] ; p<0.01)$, with a daily intake per $\mathrm{kg}$ body weight of 1.0 $(\mathrm{SD}=0.4)$ for people with normal weight status and $0.7(\mathrm{SD}=0.2)$ for obese people, while the recommendation is for $1.2 \mathrm{~g}$ protein per $\mathrm{kg}$ body weight.

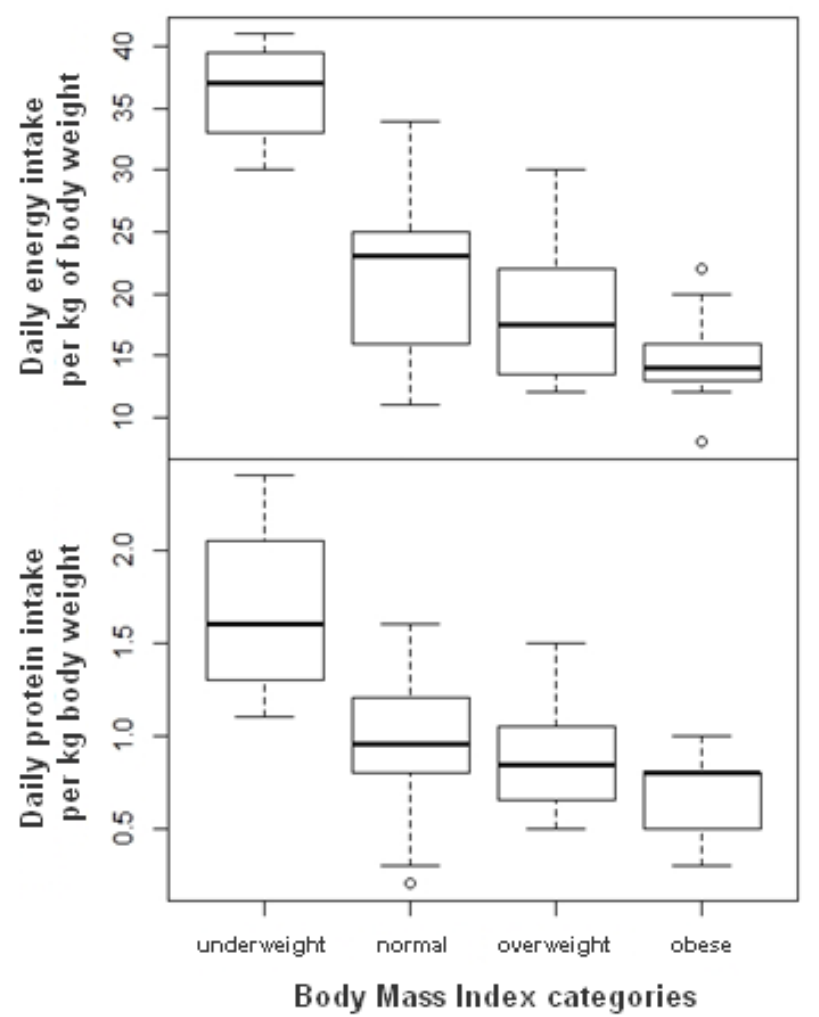

Figure 1. The boxplots of daily energy and protein intakes relative to body weight (DNIs) by weight status (BMI) of participants.

Finally, the energy and protein intakes were still associated with a significant effect of the number of meals delivered per day in a multiple linear regression model. Thus, people receiving two or three meals per day had higher energy and protein intakes than people receiving only one (total energy: $\beta=340.13$; CI: [175.24; 505.02]; $p<0.001$; total protein: $\beta=16.11$; CI: $[175.24 ; 505.02] ; p<0.001)$. Similar patterns were observed for the energy and protein intakes relative to body weight.

\section{Discussion}

\subsection{Inadequate Dietary Intake in View of Nutritional Recommendations}

An important finding in the present study is that a large proportion of elderly people receiving home-delivered meals that were provided by social services were not meeting their daily nutritional needs according to current recommendations. Specifically, $70 \%$ to $80 \%$ of the participants did not eat enough food to reach their energy and/or macronutrient (protein, carbohydrates, and lipids) needs. For these people, the energy and protein intakes were only about two-thirds of the recommended amount (respectively, $68 \%$ and $72 \%$ ). These results are in line with those that were reported in the systematic literature review that we conducted on a similar population [38]. Several authors have shown that the energy and/or protein intakes of elderly people receiving home-delivered meals were, on average, lower than recommended $[15,16,19,20]$. Table 6 presents a short list of studies that have estimated the prevalence of individuals who do not meet their energy and/or protein requirements (studies that were extracted from the systematic literature review by Fleury et al., 2021 [38]). The prevalence of individuals who did not meet the recommended intakes was not negligible in any study, even if the calculation methods vary from one study to another, and this prevalence tended to be higher for energy than for protein $[13,21,22,51]$. 
Table 6. The percentage of elderly people benefiting from home-delivery meals service and who do not meet their energy and protein needs.

\begin{tabular}{|c|c|c|c|}
\hline $\begin{array}{l}\text { Author (s), Year } \\
\text { Country }\end{array}$ & Population & Energy Intakes & Protein Intakes \\
\hline $\begin{array}{l}\text { Our Study } \\
\text { France }\end{array}$ & $\begin{array}{l}64 \text { beneficiaries of a } \\
\text { home-delivery meals service } \\
\text { (social services center of the city } \\
\text { of Paris) }\end{array}$ & $\begin{array}{l}83 \% \text { did not meet the } \\
\text { recommendations of } 30 \mathrm{kcal} \\
\text { per day per } \mathrm{kg} \text { of } \\
\text { body weight }\end{array}$ & $\begin{array}{l}72 \% \text { did not meet the } \\
\text { recommendations of } 1.2 \mathrm{~g} \text { of } \\
\text { protein per day per } \mathrm{kg} \text { of } \\
\text { body weight }\end{array}$ \\
\hline $\begin{array}{l}\text { Lipschitz et al, } 1985 \\
\text { USA }\end{array}$ & $\begin{array}{l}33 \text { beneficiaries of a } \\
\text { home-delivery meals service } \\
\text { (not OAA) }\end{array}$ & \multicolumn{2}{|c|}{$\begin{array}{l}35 \% \text { did not reach } 80 \% \text { of the energy and protein } \\
\text { recommendations *. }\end{array}$} \\
\hline $\begin{array}{l}\text { Ponza, } 1996 \\
\text { USA }\end{array}$ & $\begin{array}{l}818 \text { beneficiaries of a } \\
\text { home-delivery meals service } \\
\text { (OAA) }\end{array}$ & $\begin{array}{l}44 \% \text { did not reach } 2 / 3 \text { of the } \\
\text { energy recommendations } \\
(1900-2300 \mathrm{kcal} / \mathrm{d})\end{array}$ & $\begin{array}{l}14 \% \text { did not reach } 2 / 3 \text { of the } \\
\text { protein recommendations } \\
(50-63 \mathrm{~g} / \mathrm{d})\end{array}$ \\
\hline $\begin{array}{l}\text { Sharkey, } 2003 \\
\text { USA }\end{array}$ & $\begin{array}{l}279 \text { beneficiaries of a } \\
\text { home-delivery meals service } \\
\text { (OAA) }\end{array}$ & $\begin{array}{l}25 \% \text { did not reach } 2 / 3 \text { of the } \\
\text { energy recommendations * }\end{array}$ & $\begin{array}{l}25 \% \text { did not meet the protein } \\
\text { recommendations * }\end{array}$ \\
\hline $\begin{array}{l}\text { Walden et al, } 1998 \\
\text { USA }\end{array}$ & $\begin{array}{l}16 \text { beneficiaries of a } \\
\text { home-delivery meals service } \\
\text { (OAA) }\end{array}$ & $\begin{array}{l}56 \% \text { did not meet the energy } \\
\text { recommendations * }\end{array}$ & $\begin{array}{l}6 \% \text { did not meet the protein } \\
\text { recommendations * }\end{array}$ \\
\hline
\end{tabular}

OAA: Older American Act. * The authors did not specify in their article which recommendations they relied on to determine prevalence.

In France, home-delivered meal services are required to comply with a regulatory guide, the GEM-RCN. This guide is an official text that was issued by the French government to provide a framework for the nutritional quality of meals that are served by medico-social catering services. This guide sets up portion sizes and nutritional content of the meals in order to cover the nutritional needs of the target population [52]. Accordingly, the home-delivered meals should account for approximately $100 \%$ of the individual's nutritional requirements when a catering service provides an older individual with three meals per day. In our study, it was interesting to note that nutrient intake tends to increase with the number of meals delivered: people receiving two to three meals a day had higher energy and protein intakes than people receiving only one meal a day. This result should be taken with caution, because it is possible that intake measurements may have been more accurate for delivered meals than for self-prepared meals, as discussed in the study limitations. However, it is interesting to relate these results to the work of An (2015), Walden et al. (1989), and Walton et al. (2015) [3,13,14]. These three authors compared the nutritional intakes of beneficiaries on a day with meal delivery and on a day without. These three studies found that the energy and protein intakes were lower when people prepared their own meals than when they received meals-on-wheels service. In addition, Fleury et al. (2021) showed that one-third of their population receiving home-delivered meals did not consume their delivery all at once, but preferred to spread the food over several meals (e.g., the main course is eaten at lunch, while the starter, the bread, and the cheese are eaten at dinner) [2].

In our sample, $69 \%$ of the participants received no more than one meal per day. However, other reasons can be proposed to explain the insufficient nutritional intake that was observed in the present study, regardless of the number of meals that were delivered per day. On the one hand, some studies reported the dissatisfaction of older people regarding the sensory quality of home-delivered meals $[2,53,54]$. For instance, users' complaints relate to meat texture (too hard), seasoning, or menu variety. On the other hand, several factors that are related to aging have been shown to have a negative impact on appetite and food intake [55]. Some are related to the physiological processes of aging (less efficient digestion, alteration of hormonal mechanisms regulating hunger and satiety, decline in the ability to perceive food odors and flavors, and loss of teeth). Other social factors can be implicated in decreased food intake and/or increased nutritional risk, for example, 
insufficient financial resources or loneliness (e.g., as a result of widowhood) [56,57], which has been associated with a decrease in calorie intake [58] and food variety [59]. Finally, factors that are related to physical capacities and health status may alter food intake. For example, physical disabilities affecting one's ability to purchase groceries and/or cook may affect food choices and nutritional intake [57]. The univariate regressions in our study showed a relationship between the energy and protein intakes per body weight and the simplified SPPB score reflecting participants' motor skills: the more mobile the participants were, the higher the protein intake per kg body weight (this effect disappeared in multiple regression). Finally, the presence of comorbidities (e.g. cancer, depression, cardiovascular disease, and chronic infection) is frequently associated with a loss of appetite and an increase in nutritional risk [60]. However, in our study, we observed a negative correlation between the total energy and protein intakes and the number of comorbidities: the more comorbidities a person has, the higher his/her nutrient intakes are. This result is difficult to explain, and future research will have to focus on clarifying this link between food intake and chronic illness, particularly when considering the type of illness and the fatigue and pain associated with each condition.

Insufficient food intake (especially energy and protein) is accompanied by an increased risk of undernutrition, as indicated in the introduction. Here, we observed a correlation between the MNA score, which reflects nutritional status, as well as total energy and protein intakes: the lower the intakes, the higher the risk of undernutrition. A correlation between the MNA score and energy intake has already been reported [61,62]. More recently, the Global Leadership Initiative on Malnutrition (GLIM) consortium reviewed the criteria for diagnosing undernutrition, and included "decreased food intake" as an etiological diagnostic criterion for the adult population [30].

The insufficient food consumption observed in our study and reported in the scientific literature should lead home-delivery meal companies to further develop their offer. Two ways could be explored to enable the beneficiaries of a home-delivery meals service to better reach the nutritional recommendations. A good place to start could be improving meals' quality, from both a nutritional and sensory perspective. From a nutritional point of view, the meals delivered could be enriched (i.e., increase the energy and/or protein density of the meals without increasing the portion size), which has been recognized as relevant for increasing the food intake of small eaters [63]. From a sensory point of view, the sensory qualities of the meals delivered could be optimized (meat texture, seasoning) to better match the expectations and preferences of elderly consumers. This approach, which consists of reworking recipes that are based on the results of tests carried out among the elderly, has proven to be effective in increasing eating pleasure and food intake in retirement homes $[64,65]$. A second way could be to promote more complete home-delivered meal services, covering more meals and not just one meal per day of a few meals per week. One of the first barriers to resolve is obviously of an economic nature. Economic constraints meant that many older people received a limited number of meals, despite social assistance. However, beyond this key issue, several older people are reluctant to receive a complete offer because they want to maintain a certain autonomy regarding their food-to keep some freedom in relation to their meals [2]. Increasing the user-friendliness of these services by improving, for example, the presentation of meals, the choice of menus and even the social environment of the meal may be an effective lever for improving the perception of home-delivered meal services and facilitating their acceptance by those who need it [57]. It would be interesting for home-delivery meals services to consider diversifying their offer (more menu options, possibility of having additional food products delivered) in order to provide their beneficiaries an opportunity to better balance food consumption throughout the day. In fact, several studies found this approach to be effective in retirement homes [65-69]. 


\subsection{A Double Misfortune: Being Simultaneously Overweight and at Risk of Undernutrition}

While being underweight $(\mathrm{BMI} \leq 18)$ is a criterion of undernutrition [24], being overweight or obese does not protect against undernutrition. In our study, 55\% ( $n=35)$ of the participants were overweight or obese. Among these participants, $69 \%(n=24)$ were at risk of undernutrition or undernourishment, which represented $37 \%$ of the total sample. Data from the scientific literature show that the prevalence of nutritional risk (also measured with the MNA questionnaire) varies from $21 \%$ [70] to $50 \%$ [71] for older people with a BMI greater than 25. In overweight or obese individuals, the progressive loss of muscle mass is often accompanied by an increase and redistribution of fat mass [72], and it often goes unnoticed $[73,74]$. This "sarcopenic obesity" is associated with an increased risk of comorbidities and mortality: Batsis et al. (2014) showed that obese and sarcopenic women had a higher risk of mortality than non-obese or non-sarcopenic women [75].

The results of our study showed a positive and significant association between nutritional intake in relation to body weight and BMI: the higher a person's BMI, the more the daily energy and protein intake by $\mathrm{kg}$ of body weight decreases. This expected result raises the question of whether it is appropriate to define nutritional recommendations according to weight. Estimating recommendations based on resting energy expenditure might be an alternative. However, the formula put forward by Harris and Benedict [76] to calculate this expenditure has not been validated for the elderly population. Another alternative would be to estimate the requirements based on an "adjusted" weight (e.g., corresponding to a BMI of 25), but the notion of an "ideal" weight is not very relevant in overweight patients. However, this result also highlights the "double misfortune" that is experienced by overweight or obese elderly people. Firstly, overweight or obese people have an increased risk of developing metabolic diseases [77] and, secondly, they have difficulty in meeting nutritional recommendations and may, therefore, have an increased risk of undernourishment. The issue of undernutrition in overweight people is likely to become a major issue in the future, because of both the aging of the population and the increasing prevalence of overweight and obesity in the general population. In France, it is estimated that $63 \%$ of people aged between 65 and 74 and $57 \%$ of people over 75 are overweight or obese [78]. However, the management of overweight elderly people at risk of undernutrition is complex (see the literature review published by Porter Starr et al., 2014 [79]). It seems that interventions combining a diet for weight loss and regular physical exercise are effective if an adequate protein intake is maintained [80].

\subsection{Limitations of the Study}

The relatively small sample size is the first limitation of the study, which limits the generalization of our results (this limitation is found in two similar studies that are mentioned in Table 6: Lipschitz et al., 1985, Walden et al., 1998 [13,51]). Our initial goal was to recruit about 100 participants. However, after seven months of recruitment and 694 telephone calls, we only managed to include 64 participants. Other authors have also described difficulties recruiting dependent elderly people, especially those benefiting from a home-delivered meal service. For instance, Houston et al. (2015) and Ziylan et al. (2017) only managed to include $14 \%$ of the elderly people that they contacted $[42,81]$. The researchers contacted 486 and 300 individuals, respectively, for a final recruitment of 68 and 42 participants. In the study conducted by Arjuna et al. (2018), the inclusion rate was only $24 \%$ for a final enrollment of 29 participants. In our study, it is worth noting that the participants were recruited among people benefiting from social services in Paris [40]. These participants would be expected to have relatively low incomes and education levels, and previous studies have suggested that recruiting participants with a low socio-economic status was five to six times more difficult than recruiting participants with an intermediate socio-economic status $[82,83]$.

A second limitation of the study concerns the recording of food consumption. Although performing three 24-hour records is considered to be a reference method for assessing nutrient intakes $[84,85]$, we chose to perform only one 24 -hour record so that 
the constraints that are associated with the research would remain acceptable to the participants, who are easily fatigued. Arjuna et al. (2018), Gollub \& Weddle (2004), and Ziylan et al. (2017) used a similar approach-these studies also involved elderly people who received home-delivery meals service [40-42]. In order to ensure that the measurement was as accurate as possible, the dietitian called the participant to remind him/her to record all his/her consumption and possibly to keep the leftovers on the measurement day. Finally, during the interview, the dietitian used the delivery meal menus to help people remember what they had eaten and looked at the leftovers in the refrigerator.

\title{
5. Conclusions
}

Among the elderly people benefiting from home-delivered meals that are offered by the social services of Paris, the consumption of seven to eight out of 10 participants was below the current recommended nutritional intake for energy and macronutrients. The nutrient intake tended to increase with the number of meals delivered: people receiving two to three meals a day had higher energy and protein intakes than people receiving only one meal a day. In this population, insufficient energy and protein intake was accompanied by an increased risk of undernutrition. In fact, a correlation was observed between the nutritional status, as measured by the MNA questionnaire, and the total energy and protein intakes: the lower the intakes, the higher the risk of undernutrition.

These results should be viewed with caution, as they rely on a single 24-hour dietary record. Additional research is needed to confirm them, but also to explore why homedelivered meal beneficiaries do not reach the recommended intakes. However, the present study, in line with pervious published studies, suggests that it is important for meal delivery companies to optimize the quality of their meals and services to improve their beneficiaries' likelihood of eating well and maintaining their health.

Author Contributions: The authors' contributions were distributed as follows: S.F.-research, resource provision, data collection, writing. V.V.W.-D.-editing and proofreading. B.L.-editing and proofreading. P.T.- - validation, editing and proofreading, obtaining funding. I.M.- supervision, coordination. C.S.-R.-conceptualization, writing, visualization, obtaining funding. All authors have read and agreed to the published version of the manuscript.

Funding: This study is part of the RENESSENS project which was funded by the French National Research Agency (ANR-13-ALID-0006-02). This work was also subsidized by the Regional Council of Burgundy France (PARI Agral 1) and the European Regional Economic Development Fund (FEDER).

Institutional Review Board Statement: All procedures performed in the studies were in accordance with the ethical standards of the institutional research committee and with the declaration of Helsinki and its later amendments. Informed consent was obtained from all individual participants included in the studies. The experimental protocol was approved by the appropriate French ethics committee (CPP ESTI 2015/24-IDRCB N² 2015-A01324-45).

Informed Consent Statement: Informed consent was obtained from all subjects involved in the study.

Data Availability Statement: To request the complete data tables please contact the corresponding author.

Acknowledgments: The authors would like to thank Hélène Cabanes, Marion Perruchaud and Anaïs Roger for their logistical and technical assistance during the study and Suzanne Rankin from the Dijon Bourgogne University Hospital for editing the manuscript.

Conflicts of Interest: At the time of the study, the authors attached to Saveurs et Vie belonged to the company, private partner of the RENESSENS.

\author{
Abbreviations \\ BMI Body Mass Index \\ MNA Mini Nutritional Assessment \\ SPPB Short Physical Performance Battery
}




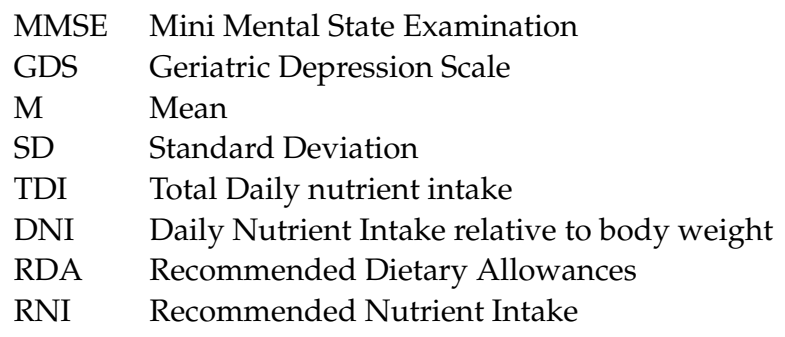

\section{References}

1. Cardon, P.; Gojard, S. Les personnes âgées face à la dépendance culinaire: Entre délégation et remplacement. La Documentation française. Retraite Soc. 2008, 4, 169-193.

2. Fleury, S.; Sulmont-Rossé, C.; Tronchon, P.; Wymelbeke, V.V.; Roux, S. Le portage de repas à domicile: Processus d'installation et d'appropriation de ce service par les personnes âgées en perte d'autonomie. Nutr. Clin. Metab. 2021, 35, 107-115. [CrossRef]

3. An, R. Association of Home-Delivered Meals on Daily Energy and Nutrient Intakes: Findings from the National Health and Nutrition Examination Surveys. J. Nutr. Gerontol. Geriatr. 2015, 34, 263-272. [CrossRef] [PubMed]

4. $\quad$ Buys, D.R.; Marler, M.L.; O Robinson, C.; Hamlin, C.M.; Locher, J.L. Recruitment of volunteers for a home-delivered meals programme serving homebound older adults: A theoretically derived programme among faith communities. Public Health Nutr. 2010, 14, 1473-1478. [CrossRef] [PubMed]

5. Dewar, M.; Dickinson, A.; Smeeton, N. Tracking and treating malnutrition: A retrospective observational study of the nutritional status of vulnerable people accessing a meals-on-wheels (MOW) service. Prim. Health Care Res. Dev. 2020, 21, 19. [CrossRef]

6. Frongillo, E.A.; Wolfe, W.S. Impact of Participation in Home-Delivered Meals on Nutrient Intake, Dietary Patterns, and Food Insecurity of Older Persons in New York State. J. Nutr. Elder. 2010, 29, 293-310. [CrossRef] [PubMed]

7. Keller, H.H. Meal Programs Improve Nutritional Risk: A Longitudinal Analysis of Community-Living Seniors. J. Am. Diet. Assoc. 2006, 106, 1042-1048. [CrossRef] [PubMed]

8. Lindhardt, T.; Nielsen, M. Older patients' use of technology for a post-discharge nutritional intervention - A mixed-methods feasibility study. Int. J. Med. Inform. 2017, 97, 312-321. [CrossRef] [PubMed]

9. Marceaux, S. The Impact of Participation in Meals on Wheels and More (MOWAM) in Austin, TX, on Dietary Intake and Health Status. Ph.D. Thesis, Texas State University-San Marcos, San Marcos, TX, USA, 2012.

10. O'Leary, M.F.; Barreto, M.; Bowtell, J.L. Evaluating the Effect of a Home-Delivered Meals Service on the Physical and Psychological Wellbeing of a UK Population of Older Adults - A Pilot and Feasibility Study. J. Nutr. Gerontol. Geriatr. 2019, 39, 1-15. [CrossRef] [PubMed]

11. Roy, M.-A.; Payette, H. Meals-on-wheels improves energy and nutrient intake in a frail free-living elderly population. J. Nutr. Health Aging 2006, 10, 554-560. [PubMed]

12. Ullevig, S.L.; Sosa, E.T.; Crixell, S.; Uc, E.; Greenwald, B.; Marceaux, S.; Friedman, B.J. Impact of Home-Delivered Meals on Nutrition Status and Nutrient Intake among Older Adults in Central Texas. J. Nutr. Health Aging 2018, 22, 861-868. [CrossRef] [PubMed]

13. Walden, O.; Hayes, P.A.; Lee, D.Y.; Montgomery, D.H. The Provision of Weekend Home Delivered Meals by State and a Pilot Study Indicating the Need for Weekend Home Delivered Meals. J. Nutr. Elder. 1989, 8, 31-43. [CrossRef] [PubMed]

14. Walton, K.; Charlton, K.; Manning, F.; McMahon, A.T.; Galea, S.; Evans, K. The nutritional status and energy and protein intakes of MOW clients and the need for further targeted strategies to enhance intakes. Appetite 2015, 95, 528-532. [CrossRef] [PubMed]

15. Wright, L.; Vance, L.; Sudduth, C.; Epps, J.B. The Impact of a Home-Delivered Meal Program on Nutritional Risk, Dietary Intake, Food Security, Loneliness, and Social Well-Being. J. Nutr. Gerontol. Geriatr. 2015, 34, 218-227. [CrossRef]

16. Charlton, K.E.; Walton, K.; Moon, L.; Smith, K.; McMahon, A.T.; Ralph, F.; Stuckey, M.; Manning, F.; Krassie, J. “It could probably help someone else but not me": A feasibility study of a snack programme offered to meals on wheels cli-ents. J. Nutr. 2013, 17, 6. [CrossRef]

17. Frongillo, E.A.; Cantor, M.H.; Macmillan, T.; Issacman, T.D.; Sherrow, R.; Henry, M.; Wethington, E.; Pillemer, K. Who are the recipients of Meals-on-Wheels in New York City? A profile of based on a representative sample of Meals-on-Wheels recipients, part II. Care Manag. J. 2010, 11, 129-139. [CrossRef] [PubMed]

18. Hoogenboom, M.S.; Spangler, A.A.; Crose, R. Functional Status and Nutrient Intake from the Council on Aging Meal and Total Daily Intake of Congregate, Adult Day Care and Homebound Program Participants. J. Nutr. Elder. 1998, 17, 1-18. [CrossRef]

19. Krondl, M.; Lau, D.; Coleman, P.; Stocker, G. Tailoring of Nutritional Support for Older Adults in the Community. J. Nutr. Elder. 2003, 23, 17-32. [CrossRef] [PubMed]

20. MacLellan, D.L. Contribution of Home-Delivered Meals to the Dietary Intake of the Elderly. J. Nutr. Elder. 1997, 16, 17-32. [CrossRef]

21. Ponza, M. Serving Elders at Risk the Older Americans Act Nutrition Programs: National Evaluation of the Elderly Nutrition Program 1993-199. In Princeton, NJ: Mathematica Policy Research; Title III Evaluation Findings; US Department of Health and Human Services, Office of the Assistant Secretary for Aging: Washington, DC, USA, 1996; Volume I, p. 331. 
22. Sharkey, J.R. Risk and Presence of Food Insufficiency Are Associated with Low Nutrient Intakes and Multimorbidity among Homebound Older Women Who Receive Home-Delivered Meals. J. Nutr. 2003, 133, 3485-3491. [CrossRef]

23. Bresson, J.-L.; Mariotti, F. Actualisation des Repères du PNNS: Elaboration des Références Nutritionnelles. Avis de l'Anses, Rapport D'Expertise Scientifique. Edition Scientifique. 2016. Available online: https://www.anses.fr/fr/system/files/NUT201 2SA0103Ra-2.pdf (accessed on 23 October 2020).

24. Stratégie de prise en charge en cas de dénutrition protéino-énergétique chez la personne âgée: Recommandations professionnelles (2007). Med. Mal. Metab. 2007, 1, 92-96. [CrossRef]

25. Bauer, J.; Biolo, G.; Cederholm, T.; Cesari, M.; Cruz-Jentoft, A.J.; Morley, J.E.; Phillips, S.; Sieber, C.C.; Stehle, P.; Teta, D.; et al. Evidence-Based Recommendations for Optimal Dietary Protein Intake in Older People: A Position Paper From the PROT-AGE Study Group. J. Am. Med. Dir. Assoc. 2013, 14, 542-559. [CrossRef]

26. Deutz, N.E.; Bauer, J.M.; Barazzoni, R.; Biolo, G.; Boirie, Y.; Bosy-Westphal, A.; Cederholm, T.; Cruz-Jentoft, A.; Krznariç, Z.; Nair, K.S.; et al. Protein intake and exercise for optimal muscle function with aging: Recommendations from the ESPEN Expert Group. Clin. Nutr. 2014, 33, 929-936. [CrossRef] [PubMed]

27. Kaiser, M.J.; Bauer, J.M.; Ms, R.P.S.A.; Uter, W.; Guigoz, Y.; Cederholm, T.; Thomas, D.R.; Anthony, P.S.; Charlton, K.; Maggio, M.; et al. Frequency of Malnutrition in Older Adults: A Multinational Perspective Using the Mini Nutritional Assessment. J. Am. Geriatr. Soc. 2010, 58, 1734-1738. [CrossRef] [PubMed]

28. Cuthbertson, D.; Smith, K.; Babraj, J.; Leese, G.; Waddell, T.; Atherton, P.; Wackerhage, H.; Taylor, P.M.; Rennie, M.J. Anabolic signaling deficits underlie amino acid resistance of wasting, aging muscle. FASEB J. 2004, 19, 1-22. [CrossRef] [PubMed]

29. Walrand, S.; Guillet, C.; Salles, J.; Cano, N.; Boirie, Y. Physiopathological Mechanism of Sarcopenia. Clin. Geriatr. Med. 2011, 27, 365-385. [CrossRef] [PubMed]

30. Cederholm, T.; Jensen, G.L.; Correia, M.I.T.D.; Gonzalez, M.C.; Fukushima, R.; Higashiguchi, T.; Baptista, G.; Barazzoni, R.; Blaauw, R.; Coats, A.; et al. GLIM criteria for the diagnosis of malnutrition-A consensus report from the global clinical nutrition community. Clin. Nutr. 2019, 38,1-9. [CrossRef]

31. Ahmed, T.; Haboubi, N. Assessment and management of nutrition in older people and its importance to health. Clin. Interv. Aging 2010, 5, 207-216. [CrossRef] [PubMed]

32. Charlton, K.; Nichols, C.; Bowden, S.; Milosavljevic, M.; Lambert, K.; Barone, L.; Mason, M.; Batterham, M. Poor nutritional status of older subacute patients predicts clinical outcomes and mortality at 18 months of follow-up. Eur. J. Clin. Nutr. 2012, 66, 1224-1228. [CrossRef]

33. Akner, G.; Cederholm, T. Treatment of protein-energy malnutrition in chronic nonmalignant disorders. Am. J. Clin. Nutr. 2001, 74, 6-24. [CrossRef]

34. Barker, L.A.; Gout, B.S.; Crowe, T.C. Hospital Malnutrition: Prevalence, Identification and Impact on Patients and the Healthcare System. Int. J. Environ. Res. Public Health 2011, 8, 514-527. [CrossRef] [PubMed]

35. Salminen, K.S.; Suominen, M.H.; Kautiainen, H.; Pitkälä, K.H. Associations between Nutritional Status, Frailty and Health-Related Quality of Life Among Older Long-Term Care Residents in Helsinki. J. Nutr. Health Aging 2020, 24, 319-324. [CrossRef]

36. Masson, Y. Management et Ingénierie en Restauration Collective. Module 1: Bases sur la Restauration Collective. Master 1 Alimentation MIRC + SSAA. 2015. Available online: http://www.isthia.fr/master-sciences-sociales-mirc-481.html (accessed on 23 October 2020).

37. Bardez, C.; Cressens, M.; Hilaire, A.; Lyannaz, S.; Montignies, J.; Costa, B.; Etchetto, C.; Kohler, C.; Michelot, J. Personnes Âgées Vivant à Domicile, le Portage de Repas: Élément Essentiel de Lutte Contre la Dénutrition? Module Interpro-Fessionnel de Santé Publique, Ecole des Hautes Etudes en Santé Publique (EHESP); EHESP (Ecole Des Hautes Etudes En Santé Publique): Rennes, France, 2008.

38. Fleury, S.; Tronchon, P.; Rota, J.; Meunier, C.; Mardiros, O.; Van Wymelbeke-Delannoy, V.; Sulmont-Rossé, C. The Nutritional Issue of Older People Receiving Home-Delivered Meals: A Systematic Review. Front. Nutr. 2021, 8. [CrossRef] [PubMed]

39. Borkent, J.W.; Beelen, J.; Linschooten, J.O.; Roodenburg, A.J.C.; De Van Der Schueren, M.A.E. The ConsuMEER study: A randomised trial towards the effectiveness of protein-rich ready-made meals and protein-rich dairy products in increasing protein intake of community-dwelling older adults after switching from self-prepared meals towards ready-made meals. J. Nutr. Sci. 2019, 8, e30. [CrossRef] [PubMed]

40. Arjuna, T.; Miller, M.; Soenen, S.; Chapman, I.; Visvanathan, R.; Luscombe-Marsh, N.D. Serve Size and Estimated Energy and Protein Contents of Meals Prepared by 'Meals on Wheels' South Australia Inc.: Findings from a Meal Audit Study. Foods 2018, 7, 26. [CrossRef] [PubMed]

41. Gollub, E.A.; Weddle, D.O. Improvements in nutritional intake and quality of life among frail homebound older adults receiving home-delivered breakfast and lunch. J. Am. Diet. Assoc. 2004, 104, 1227-1235. [CrossRef] [PubMed]

42. Ziylan, C.; Haveman-Nies, A.; Kremer, S.; de Groot, L.C. Protein-Enriched Bread and Readymade Meals Increase CommunityDwelling Older Adults' Protein Intake in a Double-Blind Randomized Controlled Trial. J. Am. Med. Dir. Assoc. 2017, 18, 145-151. [CrossRef]

43. Ciqual: Table de Composition Nutritionnelle des Aliments. Available online: https://ciqual.anses.fr/ (accessed on 23 October 2020).

44. Guide Pratique du Poids des Vêtements et Tissus en Machine: Jean, Serviette, t-Shirt, (n.d.). IDEAL. Available online: https: //www.ideal.fr/guide/ poids-et-quantite-de-linge/ (accessed on 19 October 2020). 
45. Chumlea, W.C.; Roche, A.F.; Steinbaugh, M.L. Estimating Stature from Knee Height for Persons 60 to 90 Years of Age. J. Am. Geriatr. Soc. 1985, 33, 116-120. [CrossRef] [PubMed]

46. Guigoz, Y.; Lauque, S.; Vellas, B.J. Identifying the elderly at risk for malnutrition The Mini Nutritional Assess-ment. Clin. Geriatr. Med. 2002. [CrossRef]

47. Guralnik, J.M.; Simonsick, E.M.; Ferrucci, L.; Glynn, R.J.; Berkman, L.F.; Blazer, D.G.; Scherr, P.A.; Wallace, R.B. A Short Physical Performance Battery Assessing Lower Extremity Function: Association with Self-Reported Disability and Prediction of Mortality and Nursing Home Admission. J. Gerontol. 1994, 49, M85-M94. [CrossRef]

48. Folstein, M.F.; Folstein, S.E.; McHugh, P.R. "Mini-mental state". A practical method for grading the cognitive state of patients for the clinician. J. Psychiatr. Res. 1975, 12, 189-198. [CrossRef]

49. Mitchell, A.J.; Bird, V.; Rizzo, M.; Meader, N. Diagnostic validity and added value of the geriatric depression scale for depression in primary care: A meta-analysis of GDS30 and GDS15. J. Affect. Disord. 2010, 125, 10-17. [CrossRef]

50. Yesavage, J.A.; Sheikh, J. 9/Geriatric Depression Scale (GDS). Clin. Gerontol. 1986, 5, 165-173. [CrossRef]

51. Lipschitz, D.A.; Mitchell, C.O.; Steele, R.W.; Milton, K.Y. Nutritional Evaluation and Supplementation of Elderly Subjects Participating in a "Meals on Wheels" Program. J. Parenter. Enter. Nutr. 1985, 9, 343-347. [CrossRef] [PubMed]

52. GEM-RCN. Recommandations Nutritionnelles Pour Les Personnes Agées. Version 1.0 Juillet 2015. Available online: http: / / www.gemrcn.fr/ (accessed on 10 July 2020).

53. CLCV. Enquête sur L'alimentation des Personnes Âgées. 2012. Available online: http://www.clcv.org/nos-enquetes/enquetesur-1-alimentation-des-personnes-agees-02-02-2012.html (accessed on 15 December 2020).

54. Lesourd, B.; Dadet, S. Portage de repas à domicile: Quel rôle et quelle efficacité ? Cah. L'année Gerontol. 2013, 5, 318-325. [CrossRef]

55. Inzitari, M.; Doets, E.; Bartali, B.; Benetou, V.; Di Bari, M.; Visser, M.; Volpato, S.; Gambassi, G.; Topinkova, E.; De Groot, L.; et al. Nutrition in the age-related disablement process. J. Nutr. Health Aging 2011, 15, 599-604. [CrossRef] [PubMed]

56. Rosenbloom, C.A.; Whittington, F.J. The Effects of Bereavement on Eating Behaviors and Nutrient Intakes in Elderly Widowed Persons. J. Gerontol. 1993, 48, S223-S229. [CrossRef] [PubMed]

57. Van Der Pols-Vijlbrief, R.; Wijnhoven, H.; Visser, M. Perspectives on the causes of undernutrition of community-dwelling older adults: A qualitative study. J. Nutr. Health Aging 2017, 21, 1200-1209. [CrossRef]

58. Locher, J.L.; Robinson, C.O.; Roth, D.L.; Ritchie, C.S.; Burgio, K.L. The Effect of the Presence of Others on Caloric Intake in Homebound Older Adults. J. Gerontol. Ser. A Boil. Sci. Med. Sci. 2005, 60, 1475-1478. [CrossRef]

59. Kimura, Y.; Wada, T.; Okumiya, K.; Ishimoto, Y.; Fukutomi, E.; Kasahara, Y.; Chen, W.; Sakamoto, R.; Fujisawa, M.; Otsuka, K.; et al. Eating alone among community-dwelling Japanese elderly: Association with depression and food diversity. J. Nutr. Health Aging 2012, 16, 728-731. [CrossRef]

60. Berry, E.M.; Marcus, E.-L. Disorders of Eating in the Elderly. J. Adult Dev. 2000, 7, 87-99. [CrossRef]

61. Murphy, M.; Brooks, C.; New, S.; Lumbers, M. The use of the Mini-Nutritional Assessment (MNA) tool in elderly orthopaedic patients. Eur. J. Clin. Nutr. 2000, 54, 555-562. [CrossRef] [PubMed]

62. Vellas, B.; Guigoz, Y.; Baumgartner, M.; Garry, P.J.; Lauque, S.; Albarede, J.-L. Relationships between nutritional markers and the mini-nutritional assessment in 155 older persons. J. Am. Geriatr. Soc. 2000, 48, 1300-1309. [CrossRef] [PubMed]

63. Herrera, J.C.M.; Martinsantos, F.J.; Carobautista, J.; Figueredo, M.C.S.; Garciamayor, S.; Morales-Asencio, J.M. Effectiveness of food-based fortification in older people a systematic review and meta-analysis. J. Nutr. Health Aging 2016, 20, 178-184. [CrossRef] [PubMed]

64. Sulmont-Rossé, C.; Maître, I.; Feyen, V.; Vandenberghe-Descamps, M.; Labouré, H.; Feron, G.; Van Wymelbeke, V. Quels aliments pour maintenir la prise alimentaire chez les personnes âgées et prévenir la dénutrition? Innov. Agron. 2018, 65, 99-111. [CrossRef]

65. Van Wymelbeke, V.; Sulmont-Rossé, C.; Feyen, V.; Issanchou, S.; Manckoundia, P.; Maître, I. Optimizing sensory quality and variety: An effective strategy for increasing meal enjoyment and food intake in older nursing home residents. Appetite 2020, 153, 104749. [CrossRef] [PubMed]

66. Desai, J.; Winter, A.; Young, K.W.; Greenwood, C.E. Changes in Type of Foodservice and Dining Room Environment Preferentially Benefit Institutionalized Seniors with Low Body Mass Indexes. J. Am. Diet. Assoc. 2007, 107, 808-814. [CrossRef]

67. Elmståhl, S.; Blabolil, V.; Fex, G.; Küller, R.; Steen, B. Hospital nutrition in geriatric long-term care medicine. I. Effects of a changed meal environment. Compr. Gerontol. Sect. A Clin. Lab. Sci. 1987, 1, 29-33.

68. Kremer, S.; Derks, J.; De Vries, M.N.; Boer, E.P.J.; Gorselink, M. Effect of a holistic meal and ambiance concept on main meal enjoyment and food intake of dutch nursing home residents: A pilot study. J. Aging Res. Clin. Pract. 2012, 1, $237-244$.

69. Nijs, K.A.N.D.; De Graaf, C.; Kok, F.J.; A Van Staveren, W. Effect of family style mealtimes on quality of life, physical performance, and body weight of nursing home residents: Cluster randomised controlled trial. BMJ 2006, 332, 1180-1184. [CrossRef]

70. Oehlschlaeger, M.H.K.; Pastore, C.A.; Cavalli, A.S.; Gonzalez, M.C. Nutritional status, muscle mass and strength of elderly in southern Brazil. Nutr. Hosp. 2014, 31, 363-370. [CrossRef]

71. Özkaya, I.; Gürbüz, M. Malnourishment in the overweight and obese elderly. Nutr. Hosp. 2019, 36, 39-42. [CrossRef]

72. Roubenoff, R. Sarcopenic Obesity: The Confluence of Two Epidemics. Obes. Res. 2004, 12, 887-888. [CrossRef]

73. Cetin, D.C.; Nasr, G. Obesity in the elderly: More complicated than you think. Clevel. Clin. J. Med. 2014, 81, 51-61. [CrossRef] [PubMed] 
74. Oreopoulos, A.; McAlister, F.A.; Kalantar-Zadeh, K.; Padwal, R.; Ezekowitz, J.; Sharma, A.M.; Kovesdy, C.P.; Fonarow, G.; Norris, C.M. The relationship between body mass index, treatment, and mortality in patients with established coronary artery disease: A report from APPROACH. Eur. Heart J. 2009, 30, 2584-2592. [CrossRef] [PubMed]

75. Batsis, J.A.; Mackenzie, T.A.; Barre, L.K.; LopezJimenez, F.; Bartels, S.J. Sarcopenia, sarcopenic obesity and mortality in older adults: Results from the National Health and Nutrition Examination Survey III. Eur. J. Clin. Nutr. 2014, 68, 1001-1007. [CrossRef]

76. Harris, J.A.; Benedict, F.G. A Biometric Study of Human Basal Metabolism. Proc. Natl. Acad. Sci. USA 1918, 4, 370-373. [CrossRef] [PubMed]

77. Waters, D.L.; Ward, A.L.; Villareal, D.T. Weight loss in obese adults 65years and older: A review of the controversy. Exp. Gerontol. 2013, 48, 1054-1061. [CrossRef]

78. Eurostat. Eurostat, hlth_ehis_bm1i, Données. 2014. Available online: https://appsso.eurostat.ec.europa.eu (accessed on 3 December 2020).

79. Starr, K.N.P.; McDonald, S.R.; Bales, C.W. Obesity and Physical Frailty in Older Adults: A Scoping Review of Lifestyle Intervention Trials. J. Am. Med. Dir. Assoc. 2014, 15, 240-250. [CrossRef]

80. Bouchonville, M.F.; Villareal, D.T. Sarcopenic obesity. Curr. Opin. Endocrinol. Diabetes Obes. 2013, 20, 412-419. [CrossRef]

81. Houston, D.K.; Tooze, J.A.; Demons, J.L.; Davis, B.L.; Shertzer-Skinner, R.; Kearsley, L.B.; Kritchevsky, S.B.; Williamson, J.D. Delivery of a Vitamin D Intervention in Homebound Older Adults Using a Meals-on-Wheels Program: A Pilot Study. J. Am. Geriatr. Soc. 2015, 63, 1861-1867. [CrossRef] [PubMed]

82. Darmon, N.; Lacroix, A.; Ruffieux, B. Experimental Economics Shows How Food Price Policies May Improve Diet While Increasing Socioeconomic Inequalities in Nutrition; Working Paper INRA; UMPF. 2011. Available online: https:/ / hal.archivesouvertes.fr/hal-02805543/ (accessed on 10 December 2020).

83. Ruffieux, B. Évaluation par L'économie Expérimentale de Politiques Nutritionnelles de Prix et D'information. In Proceedings of the Internal Workshop, Dijon France, May 2010.

84. Biró, G.; Hulshof, K.F.A.M.; Ovesen, L.; Cruz, J.A.A. For the EFCOSUM Group; Selection of methodology to assess food intake. Eur. J. Clin. Nutr. 2002, 56, S25-S32. [CrossRef] [PubMed]

85. Sun, Y.; Roth, D.L.; Ritchie, C.S.; Burgio, K.L.; Locher, J.L. Reliability and Predictive Validity of Energy Intake Measures from the 24-Hour Dietary Recalls of Homebound Older Adults. J. Am. Diet. Assoc. 2010, 110, 773-778. [CrossRef] [PubMed] 